\title{
Biofuel Sustainability and the Formation of Transnational Hybrid Governance
}

\author{
Ponte, Stefano; Daugbjerg, Carsten
}

\author{
Document Version \\ Accepted author manuscript \\ Published in: \\ Environmental Politics \\ DOI: \\ $10.1080 / 09644016.2014 .954776$ \\ Publication date: \\ 2015 \\ License \\ Unspecified
}

Citation for published version (APA):

Ponte, S., \& Daugbjerg, C. (2015). Biofuel Sustainability and the Formation of Transnational Hybrid Governance. Environmental Politics, 24(1), 96-114. https://doi.org/10.1080/09644016.2014.954776

Link to publication in CBS Research Portal

\section{General rights}

Copyright and moral rights for the publications made accessible in the public portal are retained by the authors and/or other copyright owners and it is a condition of accessing publications that users recognise and abide by the legal requirements associated with these rights.

\section{Take down policy}

If you believe that this document breaches copyright please contact us (research.lib@cbs.dk) providing details, and we will remove access to the work immediately and investigate your claim.

Download date: 26. Apr. 2023

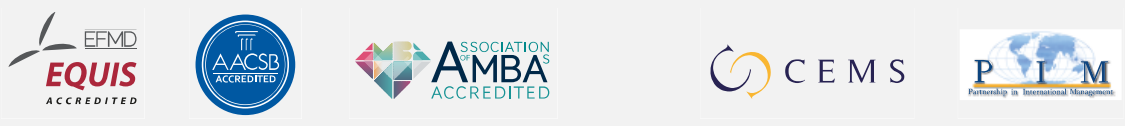




\section{Biofuel Sustainability and the Formation of Transnational Hybrid Governance}

\section{Stefano Ponte and Carsten Daugbjerg}

Journal article (Post print version)

Cite: Biofuel Sustainability and the Formation of Transnational Hybrid Governance. / Ponte, Stefano; Daugbjerg, Carsten. In: Environmental Politics, Vol. 24, No. 1, 2015, p. 96-114.

This is an Accepted Manuscript of an article published by Taylor \& Francis in Environmental Politics on 09 October २०14, available online: http://www.tandfonline.com/10.1080/09644016.2014.954776

Uploaded to Research@CBS: December २०16 


\title{
Biofuel Sustainability and the Formation of Transnational Hybrid Governance
}

\author{
Stefano Ponte* \\ Department of Business and Politics \\ Copenhagen Business School \\ Steen Blichers Vej 22 \\ 2000 Frederiksberg, Denmark \\ sp.dbp@cbs.dk
}

and

Carsten Daugbjerg,

Crawford School of Public Policy, The Australian National University

*corresponding author

\begin{abstract}
We examine the transnational governance of sustainable biofuels and its coexistence with the WTO trade regime. The analysis of how the EU Renewable Energy Directive (RED) is shaping transnational biofuel governance shows deep and mutual dependence between public and private. The EU relies on a private system of compliance and verification. At the same time, private certification schemes are dependent on the incentives provided by RED to expand commercially. A second layer of hybridity in this governance system is that it is emerging in the shadow of the WTO. EU policy makers refrained from introducing binding requirements on social sustainability criteria in RED. It was left to private certifiers to fill this gap. This article also serves as an editorial introduction to the overall symposium on the 'Transnational Hybrid Governance' (THG) of sustainable biofuels. The three articles in the symposium analyse the complex making and mutual shaping of 'sustainable biofuels' and discuss the institutional features, processes, networks and socio-technical devices by which markets are organized and economic and political orders take shape.
\end{abstract}

Keywords: transnational governance, hybridity, sustainability, biofuels

\section{Introduction}

The changing shape of transnational economic, social and environmental governance

has been a key academic and policy concern in the past decade. In particular, the shift 
from state to non-state, market-based forms of authority has been highlighted, but with a growing scholarly consensus that this development has not led to a withering away of the state. Rather, we are witnessing the birth of new hybrid governance forms where public and private come together in complex configurations that include civil society, business and a plethora of non-traditional actors.

Common to the endeavour of understanding what we call transnational hybrid governance (THG) lies a fundamental concern with the sources of legitimacy and authority that blend into regulative processes, and with the effects of different institutional designs and organizational fields on economic, social and environmental outcomes. Because THG cannot lean on the sovereignty of the state to exercise authority, particular attention has been dedicated to understanding how legitimacy is built and subsequently managed. Much of the work in this area has examined the interplay of government, civil society or business in an investigation of how they compete and/or cooperate to shape rule systems and achieve legitimacy (e.g., Bernstein and Cashore, 2007; Black, 2008; Fransen, 2012).

Governments and state agencies have actively engaged in the promotion of biofuels production and consumption. For instance, to increase domestic biofuel production, they have created incentives for farmers to grow energy crops and for fuel suppliers to use biofuels (often blended with fossil fuels). In this endeavour, they have also been concerned about the sustainability of biofuels, particularly in relation to carbon emission savings and the environmental impacts of energy crop production. But, given that a considerable share of the feedstock for biofuels consumed in the EU and the US is imported, public authorities have faced challenges in facilitating the implementation of their sustainability criteria outside their jurisdictions. Therefore, a 
number of transnational sustainability certification initiatives have emerged, which in the EU have now become the main instrument used to verify mandatory compliance with sustainability criteria.

The three papers included in this symposium discuss how transnational hybrid governance mechanisms are enacted in view of governing the 'sustainability' of biofuels. They analyse the interventions of networks of professionals, state-based bodies and institutions, and international organizations, in the complex making and mutual shaping of 'sustainable biofuels' and discuss the joint processes and sociotechnical devices by which markets are organized and economic and political orders take shape. They examine the assemblages of specific private companies, NGOs and public bodies that facilitate the construction of hybrid governance mechanisms. But they also highlight the complexity of operating THG mechanisms, given their intersection with national regulation, points of contact or parallelism with intergovernmental regimes (e.g. the WTO), and possible intra-regional disagreements (e.g. within the EU).

Our article examines the creation of hybrid sustainable biofuels governance and its coexistence with the WTO trade regime. First, we show that governance of sustainable biofuels is essentially hybrid and based on mutual dependence between public and private. The EU relies on a voluntary and private system of compliance and verification, which also helps it to apply regulatory authority beyond its territorial borders. At the same time, private certification schemes are dependent on the incentives provided by RED both to function commercially and to establish their legitimacy. Second, we argue that the THG of biofuel sustainability was built in the shadow of the inter-governmental trade regime of the WTO, or as others have framed 
it (Verbruggen, 2013), with the WTO acting as the 'gorilla in the closet'. While WTO trade rules allow more regulatory scope for environmental sustainability criteria, social sustainability rules may be deemed non-compliant with WTO rules. Indeed, it was to a considerable extent the perceived risk of being entangled in a WTO dispute that refrained EU policy makers from introducing binding requirements on social sustainability criteria in the EU biofuels policy of 2009 (Daugbjerg and Swinbank, forthcoming; Ackrill and Kay, 2011; Lydgate, 2012).

Henriksen's article shows how the interlocking boards' network of global sustainability initiatives is shaping the content and regulatory scope of standards in the biofuel sector. Through Social Network Analysis of six sustainability certification initiatives in biofuels, he finds that the institutional composition of their boards are indeed influential in determining their regulatory scope, but so are network centrality and the specific topology in which standard-setters are embedded. This means that while understanding how sustainability standards are shaped from within these MSIs is important, it is also necessary to examine them in the wider context of hybrid regulatory networks. While the current wave of studies on transnational governance is interested in hybridity, it is often seen in itself as adding to the legitimacy and actual effectiveness of governance arrangements. Henriksen shows that the link between institutional diversity and better regulatory performance is not as straightforward as the literature suggests. He also shows that network centrality is important, as it facilitates learning as a key driver of regulatory scope, and that the degree of similarity of standards in different MSIs corresponds with the similarity in their network structure. 
Finally, Laurent's paper unpacks the socio-technical devices that are expected to measure and audit 'sustainability' criteria included in the EU Renewable Energy Directive (RED) and their practical effects in the making of material categories as well as collective order. The existing literature has tended to treat politics independently from the sustainability instruments that organize the biofuel market, either through a focus on the interaction of competing interests or on the depoliticization process that transforms sustainability into a matter of calculation. Laurent's article instead shows that politics also operate through the instruments that organize biofuel markets. He examines the political nature of specific technical instruments that are brought into play in biofuel sustainability certification initiatives in the context of the EU RED, and focuses on one such device - the mass balance system - that tracks the circulation of sustainable feedstock and biofuel along the value chain. He unpacks the significance of negotiations and compromises between stakeholders in specifying the temporal and geographic validity of the sustainability credits that underpin the mass balance system. In line with the 'sociology of markets' tradition, Laurent examines the distribution of agency in socio-technical sustainability configurations, and explains how different elements are assembled in the 'joint making of economic goods, agents and collective orders'. From this point of view, the operationalization of EU RED criteria through the mass balance system qualifies biofuel as 'sustainable' (thus rendering it into an economic good), transforms actors into 'sustainable operators', as well as builds the legitimacy of the institutions involved, thus contributing to the EU project of political integration.

In the next section, we provide definitions and highlight the main debates relevant to the discussion of transnational hybrid governance. This will be followed by the 
analysis of THG formation in sustainable biofuels and its institutional co-existence with the inter-governmental regime of the WTO. In the last section, we bring together the collective contribution of the three symposium articles to these debates and provide some directions for future research.

\section{Transnational Hybrid Governance: Definitions and Debates}

\section{Definitions}

In our approach, we focus on the transnational features of governance, rather than its inter-national or global dimensions. This is in recognition that important economic, social and environmental regulation takes place outside (but also interacts with) the venues of international agreement formation, and that these processes rarely reach truly global dimensions. In other words, we focus on how 'actors from different national contexts engage in recurrent interactions of cross-border [rule-setting and legitimacy management]' (Quack, 2010: 5) and on how institutional and network building takes place.

Precursors to the THG concept include 'private' and 'non-state, market-driven' transnational governance (Bartley, 2007; Cashore 2002; Cashore et al., 2004; Bernstein and Cashore, 2007). We chose to highlight the hybrid, rather than the private or public, features of transnational governance because business, civil society and public actors interact at different levels, in parallel and intersecting arenas, and in contexts where private and civil society actors can be subject to domestic and intergovernmental legal orders (Abbot and Snidal, 2009; Quack, 2010; Verbruggen, 2013). These are dynamics that cannot neatly be characterized as private-driven or public-driven, but are indeed hybrid. An extensive literature has shown that state 
capacity has a crucial role in facilitating the emergence, implementation, and enforcement of private regulation (Gale and Haward, 2011; Foley, 2012;

Guldbrandsen, 2014; Auld, 2014), and that successful public support is more likely to happen when norms, objectives, and interests overlap between the public and private spheres (Verbruggen, 2013). In our view, THG is characterized by polyarchic and overlapping governance arenas, where interactions between a variety of private and public actors give rise to hybrid regulatory features, and where collective and individual actors engage in cross-border rule-making, implementation and enforcement activities (Mol, 2010).

\section{'Private authority', legitimacy and hybridity}

An analytical understanding of THG needs to be placed against the background of a wider debate on the putative advance and limitations of 'private authority' in governing economic, social and environmental life (Cutler et al., 1999; Hall and Biersteker, 2002; Rittberger and Nettesheim, 2008; Mol, 2010; Büthe and Mattli, 2011; Locke, 2013). This debate has been a major focus of attention in parts of the international political economy, economic geography and environmental sociology literatures in the past 15 years or so. Analyses of private authority have sought to identify emerging structures and sources of international and transnational political and rule-making authority, where authority is said to 'exist when an individual or organization has decision-making power over particular issues and is regarded as exercising that power legitimately' (Cutler et al., 1999: 5). This literature examines the reconfiguration of regulation, various forms of institutional design and the dynamics of legitimacy-making of different types of governing mechanisms (among 
many others, see Cashore 2002; Rittberger and Nettesheim, 2008; Clapp and Fuchs. 2009; Guldbrandsen, 2010; Cadman, 2011; Fransen, 201). These discussions often draw on distinctions and overlaps between output legitimacy (stringency of standards, effectiveness in actually delivering sustainability outcomes and impacts), input legitimacy (participation, inclusion, balance in the geographic origin of stakeholders) and process legitimacy (governance set-up, system management, accountability, transparency). They often seek to identify 'best institutional designs' to achieve the putative objectives of THG schemes (Bernstein and Cashore, 2007; Fransen and Kolk 2007; Quack, 2010; Auld and Guldbrandsen 2010; Tamm Hallström and Boström 2010; Guldbrandsen 2009; 2010; 2014).

The extent to which private authority has led to a wholesale retreat of the state or to new overlaps between public and private spheres is a contentious issue (Hall and Biersteker, 2002; Pattberg, 2007; Büthe, 2010; Guldbrandsen, 2010; Cadman, 2011; Locke, 2013). While there is broad common agreement that private authority is on the rise, some of the literature suggests caution and highlights its limits: private authority may actually apply to areas that were never regulated by the state to begin with; when it addresses transnational problems, private authority can actually enhance state capacity by allowing the state to escape innate constraints on authority placed by territorial borders and to focus more effectively on other areas of regulation; and, private authority often needs public authority to establish legitimacy, thus making it difficult to disentangle the two (Cashore et al., 2004; Büthe, 2010; Gale and Haward, 2011; Foley, 2012; 2013; Guldbrandsen, 2014). This suggests that what is normally conceived as private authority in contrast to public authority (e.g. Büthe and Mattli, 2011) actually has salient hybrid features. 
Hybridity has indeed increasingly become a key concern in the transnational governance literature, with new concepts and typologies to capture the shifting forms of organizational authority at play and their blending together in regulatory standardsetting. Andonova et al. (2009), for example, distinguish state and non-state actors by their institutional traits, ranging from public transnational networks that develop governance mechanism by and for public actors, to private transnational networks established by non-state actors working primarily through codes of conduct, certification and voluntary standards. In between these extremes lie a majority of THG forms that are developed in collaboration (and conflict) between state and nonstate actors. A similar argument is made in Abbott and Snidal (2009; 2010) and Mol (2010) in relation to different forms of environmental governance.

Regime complexity, institutional coexistence, experimentalist governance and orchestration

'Regime complexity' is said to arise in governance areas where there is no hegemonic power to impose rules, and where a variety of different actors operate in a number of partly overlapping (Alter and Meunier, 2009; Keohane and Victor, 2011; Overdevest and Zeitlin, 2014) or even parallel fields. Inter-governmental regimes may in fact coexist peacefully with THG despite potential legal and political conflict (Botterill and Daugbjerg, forthcoming). The literature highlights that, while regime complexity can bring with it disruptive elements of self-interest for individual actors to achieve particularistic goals (such as forum shopping, regime shifting and strategic inconsistency; see Alter and Meunier, 2009; Schleifer, 2013), it can also provide 
alternative and more flexible venues to solve economic, social and environmental problems where a more comprehensive international regime has so far failed to emerge (Keohane and Victor, 2011; Abbot and Snidal 2009; Botterill and Daugbjerg, forthcoming).

Other contributions have examined ways in which 'experimentalist governance' may be able to solve otherwise unyieldy regulatory dilemmas. Experimentalist governance is said to be characterized by broad framework goals, coordinated learning and openness to periodical revision (Sabel and Zeitlin, 2008; Overdevest and Zeitlin, 2014). Because it is built around functional rather than structural architectures, and takes a variety of institutional forms, experimentalist governance is thought to be better able to overcome the path dependency and institutional inertia that plague international regimes (Overdevest and Zeitlin, 2014). Some authors in this literature thus encourage governments and international organizations to 'orchestrate' transnational governance architectures (Abbott and Snidal, 2010; 2014) through 'directive' or 'facilitative' means. In the former, the state attempts to incorporate governance initiatives in its regulatory framework. In the latter, the state supports these initiatives through financing, technical assistance and endorsement. Others, however, highlight that orchestration can also 'undercut rather than promote good private governance' (Schleifer, 2013: 10), create conditions for forum shopping (Ibid.; Ponte 2014b) and may actually undermine private sustainability initiatives (Bartley, 2014).

Common to this group of approaches is an interest in understanding not only the role and power of market actors in shaping THG, but also the negotiated settlements that 
arise from cooperation and conflict among firms, states, NGOs, intergovernmental institutions and other actors - with particular attention to the early stages of institutionalization, the compromised outcomes that ensue (Bartley, 2007; Auld, 2014) and the conditions that can lead to enhanced outcomes (Overdevest, 2010; Guldbrandsen, 2010; Cashore and Stone, 2014).

\section{THG formation and institutional co-existence: The case of sustainable biofuels}

\section{Biofuel sustainability standards and THG formation}

In the past decade, a considerable amount of attention has been paid to the development of biofuel industries (see, among others, Mol, 2007; Smith, 2010), with a vibrant literature examining the material and discursive formation of the 'global integrated biofuel network' (Mol, 2007) or value chain (Ponte, 2014a). Since the 1990s, governments in Brazil, the US and the EU (the main biofuel producing and consuming countries/regions) have been heavily promoting and regulating biofuels under the guise of climate change mitigation, energy security, and farmer support and rural development. But increasing food prices and the related food riots starting in 2006/07 dramatically altered this picture. Civil society groups started holding biofuel production as a major cause of increasing food prices because it takes land and water away from food production (Smith, 2010). Several studies highlighted problematic aspects of land investments, little benefit for local communities, lack of participation in decision-making at the local level, and environmental degradation (see, among many others, Vermeulen and Cotula, 2010; Clancy, 2013). Doubts also started to be cast on the impact of biofuel production on GHG emission reductions (Pimentel et al., 2010; Pimentel, 2012). 
As criticism mounted on biofuels, public regulatory bodies stepped in the fray. The EU (and several member states, including Germany and the UK) enacted directives that set sustainability standards for the production, trade and use of biofuels in member countries. The US also fine-tuned its subsidies and regulation to increase support for 'next generation' biofuels (based on biomass that does not compete directly, or indirectly, with food production) relative to first generation biofuels (those based on the processing of feedstock that can also be used for human consumption). And Brazil increased its public relations effort aimed at showing that sugarcane-based ethanol production in the country has indeed a positive impact on GHG emission reductions.

At the same time, a number of private and multi-stakeholder sustainability certification schemes emerged, ${ }^{\mathrm{i}}$ both nationally and transnationally, specifically targeted at addressing the sustainability of biofuels (or that can be applied to it) (Scarlat and Dallemand, 2011; Partzsch, 2011; Fortin, 2013; Ponte, 2014b; Moser et al. 2014). At first sight, this suggests the development of two parallel systems of transnational sustainability governance in biofuels: one public and one private; one national/regional and one transnational. But closer inspection highlights the fundamental hybrid characteristics of sustainable biofuel governance, complex interactions and overlaps between national and transnational elements, and important elements of institutional co-existence with inter-governmental regimes (see below).

The biofuel industry is increasingly becoming more globalized through a variety of processes of trans-nationalization, cross-regionalization and a few properly 'global' 
dynamics (Ponte, 2014a). This process has been accompanied by nascent forms of THG that are building bridges across arenas of national/regional regulation, and across public, private and civil society domains. These include new forms of international and cross-regional government cooperation, often with private elements, ${ }^{\mathrm{ii}}$ new international alliances in the private sector, and an increasingly complex web of cross-regional investments, with a heightened involvement of global agro-food traders, oil majors, auto and aircraft manufacturers and the aviation industry. Some truly global players that are new to the industry, or that have previously played only a marginal role, are now becoming more involved (such as Bunge, Noble Group, ADM and LouisDreyfus, to a less extent ED\&F Man). A vibrant biofuel conference circuit has become an important tool of regulatory influence and global identity formation for the industry (Ibid.).

In the 1990s, national and regional biofuel industries in systemically important producing countries and regions (Brazil, the US and the EU) were mainly governed by public regulation through minimum mandates, tariff protection, investment incentives and subsidy provision to farmers and processors. In contrast, in the contemporary governance of sustainable biofuels, other actors are playing increasingly influential regulatory functions. These include sustainability standards setters and certifiers, environmental and social NGOs, and an emerging group of business actors - providers of inputs and technology (global agro-chemical and biotech companies), producers/international traders (of feedstocks and biofuels), oil majors/distribution companies, and providers of end-use technology (airlines, aircraft and engine manufacturers, auto manufacturers) organized in a variety of biofuel sustainability initiatives and networks (Ponte, 2014a). 
The complexity of the dynamics of THG formation in biofuels can be best understood in relation to the specific experience of the formulation of sustainability standards in the EU. The most important outputs of the EU policy process on biofuel sustainability were the 2009 Renewable Energy Directive (RED) (2009/28/EC) and the Fuel Quality Directive (FQD) (2009/30/EC). RED requires 20 per cent of energy use in the EU and 10 per cent of transport fuels to come from renewable sources by $2020 .{ }^{\text {iii }}$ The Fuel Quality Directive entails the obligation for suppliers of fossil fuel to gradually reduce life cycle greenhouse gas emissions by a minimum of six per cent by 2020 (see Swinbank and Daugbjerg 2013 for a discussion on the relationship between the two directives). The directive does not prohibit the use of 'non-sustainable' biofuels, but in practice provides financial incentives through the mandate system that make them economically unviable unless they can be produced at a lower price than fossil fuels.

While the regulation of biofuel sustainability under RED may appear as straight public and domestic/regional in nature, it actually has fundamental transnational and hybrid features that are becoming increasingly complex (Franco et al., 2010; Lin, 2011; Bailis and Baka, 2011; Di Lucia, 2013; Levidow, 2013; Moser et al., 2014). First, a large proportion of biofuels consumed in the EU have to be imported, thus the EU governance system has extra-territorial implications. Second, the Commission decided to set up an accreditation system for private certification schemes that meet its criteria. Although it allows demonstration of compliance through national regulatory systems (and related assessment protocols) that meet the criteria set by the EU, and through bilateral agreements between the EU and third countries, private certification schemes have been the main compliance instrument in practice so far. In 
July 2011, the EU recognized a first batch of seven private certification schemes, followed by another six certifications in 2012. So far, one of these certification schemes (ISCC) has been dominating the EU 'market for biofuel sustainability' while the competing Roundtable for Sustainable Biomaterials (RSB), which was born transnationally (with US foundation money) and had global ambitions, has so far failed to take hold in the market (for details, see Schleifer, 2013; Ponte, 2014b; Moser et al. 2014).

The hybridity of the system is based on deep and mutual dependence and interconnection between public and private. On the one hand, the EU relies on a system of compliance and verification that is putatively voluntary and private and that can reach beyond its territorial borders. The fact that the environmental sustainability criteria are based on production process attributes which are not materially evident in the end product means that the criteria cannot be verified for imports at the border but have to be verified where they are produced. Therefore, the EU needs private certification schemes to extend its authority and capacity to implement the environmental sustainability criteria beyond its territorial borders. On the other hand, private certification schemes lean on the set of incentives set up by RED to establish their legitimacy as a market-based instrument of sustainability governance.

Governments have also played a direct or indirect role in some of these schemes. ISCC, for example, was developed mainly by a German consultant with support from the German Federal Ministry of Food, Agriculture and Consumer Protection, while the process leading to the setting of the Netherland Technical Agreement (NTA) 8080 was supported by the Dutch government. Governments are also allowed to participate 
in one of the Chambers of the RSB Assembly, although this chamber does not have voting rights.

Because THG is built around multiple regulatory arenas, lacks hegemonic actors, and has contested legitimacy, much has been made in the THG literature of the potential of interactions between different initiatives to facilitate positive collective outcomes. The discussion is often framed in terms of whether competition and/or cooperation among sustainability initiatives is leading to a 'race to the top' or a 'race to the bottom' in terms of the stringency of standards (Overdevest and Zeitlin, 2014; Bartley, 2014), with some observers providing nuanced trajectories that include 'decoupling' (change as window dressing), and the 'paradox of empty promises' (attempted decoupling that leads to further normative pressures for improvement) (Fransen, 2012).

Existing work on biofuel certifications suggests that upward normative pressures are not yet evident in the biofuel sustainability THG (Schleifer, 2013; Ponte 2014b). Commercially-oriented initiatives, such as ISCC, have established themselves strongly in the market for sustainability certification of biofuels. They are generally less democratic, leaner, quicker, and more tuned in with industry interests, and tend to more easily discriminate against small players and actors in the global South; they feature industry-dominated and top-down governance structures; and they do not attempt to give equal voice to stakeholders (Ponte, 2014b). More inclusive and democratic initiatives, such as RSB, have struggled to establish themselves in the market. At the same time, commercially-oriented initiatives are adopting seemingly more inclusive procedures and institutional features. Yet, they are doing so generally 
late in the standard development and certification process - sometimes even ex-post or as an afterthought - and in ways that heavily circumscribe effective participation by smaller or marginalized stakeholders.

This does not bode well for hopes that THG, with appropriate orchestration by national and inter-governmental public bodies (Abbott and Snidal, 2014), can deliver wished-for regulatory outcomes. Public regulation through the EU RED essentially created a captive market for biofuel sustainability, a facilitative condition not present in most other THG domains (one exception is the recent development of legal verification systems for illegal timber; see Cashore and Stone, 2014; Bartley, 2014). However, RED focused on a set of minimum standards for sustainability irrespectively of how inclusive, equitable and transparent the governance structures of the initiatives behind them are. The fastest and most aggressive mover in this context (ISCC) was able to establish a substantial presence in the market and thus close off, at least for the time being, the expansion of a far more inclusive and transparent certification system (RSB).

\section{Institutional coexistence}

To achieve its policy objects for biofuels the EU relies on an estimated import of 40 percent of its demand (German and Schoneveld 2012: 766). The trade dimension in biofuels policy-making means that the WTO legal framework became an important dimension in the policy debate in the EU. As a result, the EUs biofuels policy was designed in the shadow of the WTO. Sustainability criteria were a key issue in the debate on the biofuels component of the EU RED adopted in December 2008. An 
important concern was whether these criteria would be in compliance with WTO trade rules. While there was general agreement that the suggested environmental sustainability criteria (such as avoiding growing energy crops on land with high biodiversity value and/or high carbon stock, and minimum threshold for lifecycle GHG savings) would be compliant with the WTO legal framework, there was considerable doubt about mandatory criteria relating to social concerns, such as respecting land-use rights, improving food security in food insecure regions, or not violating labour rights. The EU Commission considered these criteria potentially in breach of WTO rules. Within the Commission 'it was felt ... that [compulsory labour standards] would overstep some countries "red lines" and thus would almost certainly trigger an action in the WTO' (Ackrill and Kay, 2011: 560). On a basis of a legal analysis, Lydgate (2012) supports this conclusion.

The distinction between process and production methods (PPM) and non-product related process and production methods (npr-PPM) $)^{\text {iv }}$ is useful in understanding why the proposed sustainability criteria could cause difficulties in the WTO. Some production process methods (PPMs) impact on the physical content of the product. States can adopt regulations defining what process requirements must be met to ensure that the end product is safe to consume or use, for instance rules on the hygienic conditions in food processing plants. Other production processes, referred to as npr-PPMs, do not leave traces that are materially evident in the end-product, but may nevertheless affect its perceived consumption value or its classification in relation to regulatory standards (Vranes, 2011). For instance, whether an energy crop used for biofuels is grown in a particular type of soil or another does not affect the physical attributes of the end product, but it can affect whether or not it can be 
classified as a biofuel product counting towards regulatory standards. In the EU RED, biofuels produced on the basis of energy crops grown on land that in January 2008 had 'high biodiversity value', a 'high carbon stock' such as forests and wetlands, or was peat land (RED, Articles 17(3), 17(4) and 17(5)) do not comply with environmental sustainability criteria. Therefore, they cannot count towards the EU's renewable energy targets. Social sustainability criteria are also based on npr-PPMs. For instance, whether or not forced labour has been used to grow an energy crop, or whether or not land rights were violated, will not affect the physical attributes of the biofuel end-product.

Government (and EU) regulations based on npr-PPMs, such as sustainability criteria, therefore sit somewhat uneasily within the WTO legal framework. The WTO trade agreements were designed with physical product characteristics and PPMs impacting on the material contents of the end product in mind. Article III of the GATT ${ }^{\mathrm{v}}$ on national treatment states that imported products from other WTO member states shall not be accorded treatment less favourable than that accorded to like products of national origin 'in respect of all laws, regulations and requirements affecting their internal sale, offering for sale, purchase, transportation, distribution or use' (art III.4) and in terms of 'internal taxes and other internal charges' (art. III.1) (a similar clause can be found in the Agreement on Technical Barrier to Trade (TBT), art. 2.1 and in art. D in its Annex 3). ${ }^{\mathrm{vi}}$ However, the exact legal meaning of the concept of 'like product' is not totally clear. How likeness is defined depends upon whether or not product processes not leaving materially evident traces in the end products can be used legitimately to distinguish between products (see Vranes 2011, 216-23 for a discussion and broad interpretation of the concept). 
GATT Article XX specifies the conditions under which policy measures that might prove inconsistent with GATT provisions (including Article III) can be maintained. One such condition is policy measures 'relating to the conservation of exhaustible natural resources if such measures are made effective in conjunction with restrictions on domestic production or consumption' (article XX $(\mathrm{g})$ ). However, GATT article XX has proved difficult to police and therefore the TBT Agreement has introduced additional disciplines. Its purpose is to ensure that both regulations (policy measures with mandatory compliance) and standards (policy measures with voluntary compliance) 'do not create unnecessary obstacles to international trade'.

The legal interpretations in relation to npr-PPM based policy measures directed towards environmental sustainability have become less strict in the WTO dispute settlement system over the last decade (Charnovitz, 2007). Provided that they are not 'more trade-restrictive than necessary to fulfil a legitimate objective', the environmental sustainability criteria are less vulnerable to legal challenge. While environmental policy measures are covered by the WTO rules and are increasingly recognized as legitimate trade concerns in WTO judicial practice, it is more uncertain how social sustainability criteria would be addressed. In particular one social sustainability concern, labour rights, has occasionally being raised in the GATT and the WTO, but the issue never became part of the WTO legal framework and has not been directly addressed in the GATT or the WTO Dispute Settlement Mechanism (Kolben, 2010: 476, Gonzalez-Garibay, 2011: 172). 
The Commission's desire to leave out social sustainability concerns from the mandatory requirements was challenged by some of the member states, most notably France, while others such as the United Kingdom and the Netherlands supported the Commission's view. But it was particularly within the European Parliament that the debate on social sustainability gained momentum. The Committee on Industry, Research and Energy (ITRE) was responsible for drafting a report on the RED proposal. It proposed to introduce a number of social sustainability criteria relating to land rights, workers' rights and food security that biofuel production had to meet. Some concerns were raised among some of the MEPs involved in the discussions that the RED social sustainability criteria might be in breach with WTO rules though a large majority within the Committee supported the inclusion of the criteria (Daugbjerg and Swinbank, forthcoming). Outside of the EU, there was also increasing concern about the sustainability criteria. Brazil and seven other biofuel-producing states from the Global South warned on 6 November 2008 that they could 'file a World Trade Organization complaint over what they see as unfair barriers being raised against their biofuels'. vii The United States shared these concerns as well. In the negotiations (the so-called trilogue) between the Commission, the Council and Parliament that led to adoption of the RED, the European Parliament negotiators backtracked on social sustainability and accepted that the Directive limited the Commission's role to report social sustainability issues every second year (Daugbjerg and Swinbank, forthcoming).

Despite the exclusion of mandatory social sustainability criteria from the RED, the pressure to address them did not disappear. In particular the food price spike of 2007/08 was believed partially to have been caused by the increased demand for 
biofuels - through the conversion of land from food and livestock feed production to biofuel feedstock production. This, combined with the view in developed countries that labour rights are a morally and legally legitimate concerns in biofuels production, maintained the desire to address the issue of social sustainability. Private certification schemes provided an alternative to government regulation. As a result, a number of private biofuels certification schemes now include social sustainability criteria, although there are significant variations in the coverage and enforcement capabilities. The EU RED-compliant versions of seven certification schemes include standards on land tenure/rights, human rights and labour rights/conditions, food security risks, and rural/social development aspects (Moser et al, 2014: 47; German and Schoneveld 2012: 771-76). Thus, the private schemes fill a gap in the governance of biofuels that the EU considers difficult to address without breaching WTO trade rules. The complementarity between EU regulation and private governance is thus a key defining feature of the hybridity of transnational governance of biofuel sustainability.

However, it is not clear whether the WTO regime and the THG of biofuel sustainability will continue to co-exist peacefully because of latent conflicts. While social sustainability criteria are not required by EU RED, some private certification schemes have included them in their protocols. Therefore, their formal recognition by the EU may come under WTO purview. In the recent Tuna II dispute between the US and Mexico, the WTO Appellate Body found that although it was voluntary for exporters of tuna products to the US to use the 'dolphin-safe' designation on their products, such labelling was a technical regulation subject to the provisions of the TBT Agreement. This was because the value chain actors wishing to use the 'dolphinsafe' label in the US market must comply with the requirements set out in the US government's Dolphin Protection Consumer Information Act (WTO 2012). By 
implication, despite the fact that private biofuel sustainability certification is not mandatory for biofuels exports to the EU market, it may be considered a technical regulation and thus subject to the provisions of the TBT agreement.

One interpretation of this situation is that the EU biofuels policy could potentially become subject to a legal challenge on social sustainability criteria in the WTO because by officially recognizing the certification schemes as EU RED-compliant the EU has indirectly made social sustainability criteria mandatory. Whether or not a legal dispute will support this interpretation remains to be seen. Only a formal legal dispute in the WTO would clarify this issue. Developing countries have generally opposed the introduction a social clause into the WTO legal framework because they consider labour standards a tool that can be used as a protectionist trade policy measure by developed countries (Kolben 2010). However, such trade restrictions do exist in EU and US trade policies, and they have not yet been challenged in the WTO Dispute Settlement Mechanism. Thus, although there is a potential legal conflict between social sustainability certification of biofuels and the WTO legal framework, it does not seem likely that this will lead to a political conflict in which developing country exporters of biofuels launch a dispute in the WTO. Kolben (2010, 475-76) explains this counter-intuitive conjecture with the reputational cost at risk for developing countries. A dispute would expose their labour conditions to a broader audience in developed countries where labour rights are considered morally and legally legitimate. 


\section{Conclusions}

We provide two sets of conclusion in this final section. The first set arises from our analysis of transnational hybrid governance and speaks to issues of orchestration and institutional coexistence. EU orchestration in biofuels has resulted in a quicker adoption of a sustainability certification system at a lower cost than would have been the case through a more traditional regulatory process (Schleifer, 2013). Indeed, it would have been difficult for environmental sustainability criteria for imported biofuels to be directly implemented by the EU, given their production process character. Since the authority of EU governments stops at the border, the only alternative option would have been bilateral agreements specifying the certification criteria in the producer country, an option included in the EU RED but not yet used by member states. At the same time, different certification schemes have widely different participatory features (Ponte, 2013b; Fortin, 2013), and orchestration has led to opportunities for forum shopping and adverse competition. This undermined the governability of biofuels more generally (Schleifer, 2013; Di Lucia, 2013), due to increasing governance needs and decreasing capacity to govern in view of conflicts among actors.

We have also shown that the THG system constructed around the EU RED was initially designed to minimize possible conflict with the WTO trade regime by leaving out social concerns from the mandatory criteria. In other words, the WTO acted as an inter-governmental 'gorilla in the closet' (Verbruggen, 2013) that influenced the THG. At the same time, some of the private certifications that are recognized by the EU RED include some social and labour issues, potentially exposing the TGH regime to (at this point unlikely) future WTO challenges. We suggest that at least so far, the 
THG of biofuel sustainability is peacefully coexisting with the inter-governmental trade regime of the WTO. At the same time, we have shown that the two have indirect and important intersections.

The second set of conclusions relates to the overall contribution of the three articles included in this symposium to the study of transnational governance more generally. The articles observe that institutional approaches have been dominant in the existing literature and that they have been useful for improving our understanding of the challenges of coordination and competition between actors belonging to different domains and acting according to different logics and capacities. At the same time, two main gaps are evident in the existing literature, which the three articles in this symposium address.

First, the articles go beyond the sharp demarcations between 'public' and 'private' in delineating the hybrid nature of transnational governance, an aspect that is both analytically underdeveloped and empirically under-researched in the current literature. In our article, we highlighted the mutual dependence between public and private in the formation of the THG of sustainable biofuels. Laurent's article shows that sustainability schemes are experimental ground on which European institutions are testing hybrid modalities of regulatory action that are expected to organize market exchange and implement policy objectives. Hybridity is thus manifested in two realms - the intermingling of private and public and, at the same time, of political and economic orders.

Second, the existing literature is almost exclusively concerned with understanding institutional interactions and the organizational features of governance, and with how 
to 'best' design these in order to achieve a putative collective goal. Henriksen's article moves beyond the literature's focus on the institutional attributes to add a network element of analysis. He shows that while institutional composition of the selected boards of multi-stakeholder initiatives is important in shaping their regulatory scope, network centrality and topology are equally key elements. Laurent's article shows the importance of examining not only organizational issues, but also the complex overlaps between the material, socio-technical and ideational content of transnational governance, as they shape both economic and political orders. Finally, our article showed that institutional coexistence is an important element for understanding the effectiveness of THG.

These observations suggests that future research on transnational governance should focus on its hybrid features, rather than its purportedly private or public components, and that institutional coexistence should come into the picture as it can indirectly shape essential features of THG and its outcomes. Further research should also unpack the network structure of fields of regulation, and could usefully examine the biographies and expertise of key individuals in these networks to understand why, how and to what extent they are capable of shaping the transnational governance of sustainability.

\section{Notes}

i These include: International Sustainability and Carbon Certification (ISCC) and the Roundtable on Sustainable Biofuels (RSB), for all types of biofuels; the Better Sugar Cane Initiative (Bonsucro), the Roundtable on Responsible Soy Association (RTRS); and the Roundtable on Sustainable Palm Oil (RSPO), for feedstock-specific biofuels; and more nationally-oriented schemes such as 2BSvs (France), Red Tractor (UK), 
Scottish Quality Farm Assured Combinable Crops Voluntary Scheme, REDcert

(Germany), and NTA8080 (the Netherlands) (see details in Ponte, 2014b).

${ }^{\text {ii }}$ For example, partly as a response to the backlash against the biofuel industry, Brazil and the US set aside their historical competitive streak in biofuels and started to collaborate in the context of a hemispheric project involving alliances with Central American actors and institutions (Hollander 2010).

${ }^{\text {iii }}$ RED sets sustainability requirements for the use of biofuels in the EU, including minimum GHG savings in comparison to fossil fuels and the double counting of credits for biofuels produced from waste and residues to decrease the impact on feedstock that can be used for food.

${ }^{\text {iv }}$ In the absence of better conceptual terms, we shall use the highly technical, but nevertheless precise and agreed concepts of PPM and npr-PPM.

${ }^{\mathrm{v}}$ http://www.wto.org/english/docs_e/legal_e/gatt47_e.pdf

${ }^{\mathrm{vi}}$ http://www.wto.org/english/docs_e/legal_e/17-tbt.pdf

vii http://www.reuters.com/article/2008/11/06/us-eu-biofuels-wtoidUSTRE4A53J620081106

\section{References}

Abbott, K.W. and Snidal, D., 2009. The governance triangle: Regulatory standards institutions and the shadow of the state. In W. Mattli and N. Woods, eds. The Politics of Global Regulation. Princeton: Princeton University Press. ADD PAGE NUMBERS 
Abbott, K.W. and Snidal, D., 2010. International regulation without international government: Improving IO performance through orchestration. Review of International Organizations, 5, 315-344.

Abbott, K.W. and Snidal, D., 2014. Taking responsive regulation transnational: Strategies for international organizations. Regulation and Governance, 7, 95113.

Ackrill, R. and Kay, A., 2011. EU Biofuels Sustainability Standards and Certification Systems - How to Seek WTO-Compatibility. Journal of Agricultural Economics, 62 (3), 551-64.

Alter, K.J. and Meunier, S., 2009. The politics of international regime complexity. Perspectives on Politics, 7, 13-24.

Andonova L.B., Betsill, M.M. and Bulkeley, H., 2009. Transnational Climate Governance. Global Environmental Politics, 9 (2), 52-73.

Auld, G., 2014. Confronting trade-offs and interactive effects in the choice of policy focus: Specialized versus comprehensive private governance. Regulation and Governance, 8 (1), 126-148.

Auld, G. and Gulbrandsen, L.H., 2010. Transparency in nonstate certification: consequences for accountability and legitimacy. Global Environmental Politics, $10(3), 97-119$.

Bailis, R. and Baka, J., 2011. Constructing sustainable biofuels: Governance of the emerging biofuel economy. Ann Assoc Am Geogr, 101 (4), 827-838. 
Bartley, T., 2007. Institutional emergence in an era of globalization: The rise of transnational private regulation of labor and environmental conditions. American Journal of Sociology, 113 (2), 297-351.

Bartley, T., 2014. Transnational governance and the re-centered state: Sustainability or legality? Regulation and Governance, 8, 93-109.

Bernstein, S. and Cashore, B., 2007. Can non-state global governance be legitimate? An analytical framework. Regulation and Governance, 1, 347-371.

Black, J., 2008. Constructing and contesting legitimacy and accountability in polycentric regulatory regimes. Regulation and Governance, 2, 137-164.

Botterill, L. and Daugbjerg, C., forthcoming. Commensalistic institutions and value conflicts: The World Trade Organization and the rise of global private food regulation. European Political Science Review. doi:10.1017/S1755773913000295

Büthe, T., 2010. Private regulation in the global economy: a (p)review. Business and Politics, 12 (3), Article 2.

Büthe, T. and Mattli, W., 2011. The New Global Rulers: The Privatization of Regulation in the World Economy. Princeton: Princeton University Press.

Cadman, T., 2011. Quality and Legitimacy of Global Governance: Case Lessons from Forestry. Basingstoke and New York: Palgrave.

Cashore, B., 2002. Legitimacy and the privatization of environmental governance: how non-state market-driven (NSMD) governance systems gain rule-making authority. Governance, 15 (4), 503-29. 
Cashore, B., Auld, G. and Newsom, D., 2004. Governing through Markets: Forest Certification and the Emergence of Non-State Authority. New Haven, CT: Yale University Press.

Cashore, B. and Stone, M.W., 2014. Does California need Delaware? Explaining Indonesian, Chinese, and United States support for legality compliance of internationally traded products. Regulation and Governance, 8, 49-73.

Charnovitz, S., 2007. The WTO's Environmental Progress. Journal of International Economic Law, 10 (3), 685-706.

Clancy, J., 2013. Biofuels and Rural Poverty. London: Earthscan.

Clapp, J. and Fuchs, D., eds., 2009. Corporate Power in Global Agrifood Governance. Cambridge, MA and London: MIT Press.

Cutler, A.C., Haufler, V. and Porter, T., 1999. Private authority and international affairs. In A.C. Cutler, V. Haufler and T. Porter, eds. Private Authority and International Affairs. Albany: State University of New York Press, 3-30.

Cutler, C., 2010. The legitimacy of private transnational governance: Experts and the transnational market for force. Socio-Economic Review, 8, 157-185.

Daugbjerg, C. and Swinbank, A., forthcoming. Globalization and new policy concerns: The WTO and EU biofuels policy. Journal of European Public Policy.

Di Lucia, L., 2013. Too difficult to govern? An assessment of the governability of transport biofuels in the EU. Energy Policy, 63, 81-88.

Dingwerth, K., 2008. Private transnational governance and the developing world: A comparative perspective. International Studies Quarterly, 52, 607-634. 
Dingwerth, K. and Pattberg, P., 2009. World politics and organizational fields: The case of transnational sustainability governance. European Journal of International Relations, 15 (4), 707-744.

Foley, P., 2012. The political economy of marine stewardship council certification: processors and access in Newfoundland and Labrador's inshore shrimp industry. Journal of Agrarian Change, 12 (2-3), 436-45.

Foley, P., 2013. National government responses to Marine Stewardship Council (MSC) fisheries certification: insights from Atlantic Canada. New Political Economy, 18 (2), 284-307.

Fortin, E., 2013. Transnational multi-stakeholder sustainability standards and biofuels: Understanding standards processes. Journal of Peasant Studies, 40 (3), 563-587.

Franco, J., Levidow, L., Fig, D., Goldfarb, L., Hönicke, M. and Mendonça, M.L., 2010. Assumptions in the European Union biofuels policy: Frictions with experiences in Germany, Brazil and Mozambique. Journal of Peasant Studies, 37 (4), 661-698.

Fransen, L., 2012. Multi-stakeholder governance and voluntary programme interactions: Legitimation politics in the institutional design of Corporate Social Responsibility. Socio-Economic Review, 10 (1), 163-192.

Fransen, L.W. and Kolk, A., 2007. Global rule setting for business: A critical analysis of multistakeholder standards. Organization, 14 (5), 667-84. 
Gale, F., and Haward, M., 2011. Global Commodity Governance: State Responses to Sustainable Forest and Fisheries Certification. Basingstoke and New York: Palgrave.

German, L. and Schoneveld, G., 2012. A review of social sustainability considerations among EU-approved voluntary schemes for biofuels, with implications for rural livelihoods. Energy Policy, 51, 765-778

Gonzalez-Garibay, M., 2011. The trade-labour and trade-environment linkages: together or apart? Journal of International Trade Law and Policy, 10 (2), 16584.

Gulbrandsen, L.H., 2009. The emergence and effectiveness of the Marine Stewardship Council. Marine Policy, 33 (4), 654-60.

Guldbrandsen, L.H., 2010. Transnational Environmental Governance: The Emergence and Effects of the Certification of Forests and Fisheries. Cheltenham: Edward Elgar.

Guldbrandsen, L.H., 2014. Dynamics governance interactions: evolutionary effects of state responses to non-state certification programs. Regulation and Governance, $8(1), 74-92$.

Hall, R.B. and Biersteker, T.J., eds., 2002. The Emergence of Private Authority in Global Governance. Cambridge: Cambridge University Press.

Hollander, G., 2010. Power is sweet: Sugarcane in the global ethanol assemblage. Journal of Peasant Studies, 37 (4), 699-721.

Keohane, R.O. and Victor, D.G., 2011. The regime complex of climate change. Perspectives on Politics, 9, 7-21. 
Kolben, K., 2010. The WTO Distraction. Stanford Law \& Policy Review, 21, 461-91.

Levidow, L., 2013. EU criteria for sustainable biofuels: accounting for carbon, depoliticizing plunder. Geoforum, 44, 211-223.

Lin, J., 2012. Governing biofuels: A principal-agent analysis of the European Union biofuels certification regime and the Clean Development Mechanism. Journal of Environmental Law, 24, 43-73.

Locke, R.M., 2013. The Promise and Limits of Private Power: Promoting Labor Standards in a Global Economy. Cambridge: Cambridge University Press.

Loconto, A. and Fouilleux, E., 2013. Politics of private regulation: ISEAL and the shaping of transnational sustainability governance. Regulation and Governance, DOI:10.1111/rego.12028.

Lydgate, E. B., 2012. Biofuels, Sustainability, and Trade-Related Regulatory Chill. Journal of International Economic Law, 15 (1), 157-80.

Mol, A.P.J., 2010. Environmental authorities and biofuel controversies. Environmental Politics, 19 (1), 61-79.

Mol, A.P.J., 2007. Boundless biofuels? Between environmental sustainability and vulnerability. Sociologia Ruralis, 47 (4), 297-315.

Moser, C., Hildebrandt, T. and Bailis, R., 2014. International sustainability standards and certification. In B.D. Solomon and E. Bailis, eds. Sustainable Development of Biofuels in Latin America and the Caribbean. New York: Springer, 27-69.

Overdevest, C., 2010. Comparing forest certification schemes: the case of ratcheting standards in the forest sector. Socio-Economic Review, 8, 47-76. 
Overdevest, C. and Zeitlin, J., 2014. Assembling an experimentalist regime:

Transnational governance interactions in the forest sector. Regulation and Governance, 8 (1), 22-48.

Partzsch, L., 2011. The legitimacy of biofuel certification. Agriculture and Human Values, 28, 413-425.

Pattberg, P.H., 2007. Private Institutions and Global Governance: The New Politics of Environmental Sustainability. Cheltenham: Edward Elgar.

Pimentel, D., 2012. Global Economic and Environmental Aspects of Biofuel. Boca Raton, FL: CRC Press.

Pimentel, D., Marklein, A., Toth, M.A., Karpoff, M.N., Paul, G.S., McCormack, R., Kyriazis, J. and Krueger, T., 2010. Why we should not be using biofuels. In Rosillo-Calle, F., Johnson, F.X., eds. Food versus Fuel: An Informed Introduction to Biofuels. London: Zed Books, 29-57.

Ponte, S., 2014a. The evolutionary dynamics of biofuel value chains: From unipolar and government-driven to multipolar governance. Environment and Planning A, 46 (2), 353-372.

Ponte, S., 2014b. 'Roundtabling' Sustainability: Lessons from the Biofuel Industry. Geoforum, DOI: 10.1016/j.geoforum.2013.07.008

Quack, S., 2010. Law, expertise and legitimacy in transnational economy governance: An introduction. Socio-Economic Review, 8, 3-16.

Rittberger, V. and Nettesheim, M., with Huckel, C., eds., 2008. Authority in the Global Political Economy. London and New York: Palgrave. 
Sabel, C.F. and Zeitlin, J., 2008. Learning from difference: The new architecture of experimentalist governance in the EU. European Law Journal, 14, 271-327.

Scarlat, N. and Dallemand, J.-F., 2011. Recent developments in biofuels/bioenergy sustainability certification: A global overview. Energy Policy, 39, (3), 1-17.

Schleifer, P., 2013. Orchestrating sustainability: The case of European Union biofuel governance. Regulation and Governance, DOI: 10.1111/rego.120373

Smith, J., 2010. Biofuels and the Globalization of Risk: The Biggest Change in NorthSouth Relationships since Colonialism? London: Zed Books.

Swinbank, A. and Daugbjerg, C., 2013. Improving EU Biofuels Policy? Greenhouse Gas Emissions, Policy Efficiency, and WTO Compatibility. Journal of World Trade, 47 (4), 813-34.

Tamm Hallström, K. and Boström, M., 2010. Transnational Multi-Stakeholder Standardization: Organizing Fragile Non-State Authority. Cheltenham: Edward Elgar.

Verbruggen, P., 2013. Gorillas in the closet? Public and private actors in the enforcement of transnational private regulation. Regulation and Governance, 7 (4), 512-532.

Vermeulen, S. and Cotula, L., 2010. Over the heads of local people: consultation, consent, and recompense in large-scale land deals for biofuels projects in Africa. Journal of Peasant Studies, 37 (4), 899-916.

Vranes, E., 2011. Climate Labelling and the WTO: The 2010 EU Ecolabelling Programme as a Test Case under WTO Law. In C. Herrmann and J. P. 
Terhechte, eds. European Yearbook of International Economic Law 2011. Berlin: SpringerVerlag, 205-37.

WTO, 2012. United States - Measures Concerning the Importation, Marketing and Sale of Tuna and Tuna Products, Report of the Appellate Body, WT/DS381/AB/R, Geneva: WTO. 